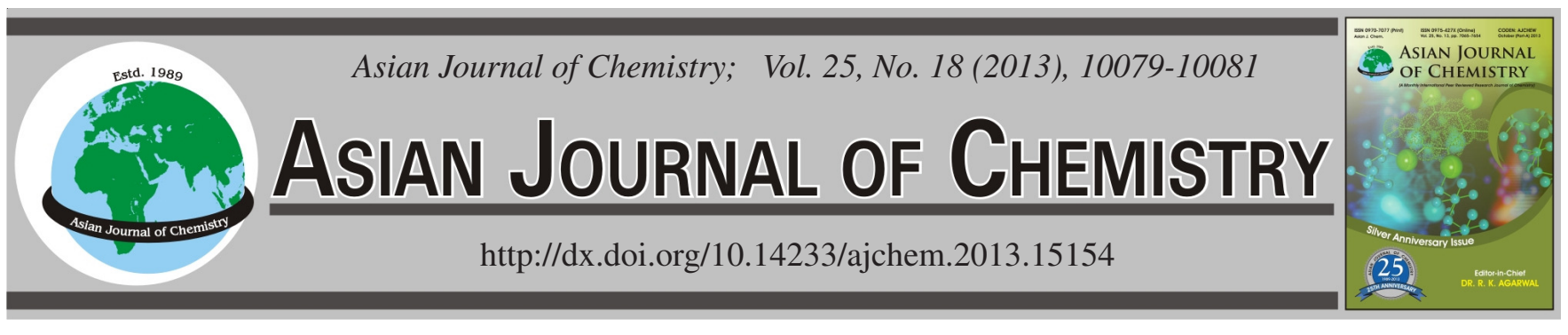

\title{
Decomposition of Chemical Nitrogen from Lightly Polluted Water with Volcanic Rocks Subsurface Wetland
}

\author{
HAO WANG ${ }^{1, *}$ and XuEJIN $\mathrm{LI}^{2}$
}

\begin{abstract}
${ }^{1}$ College of Civil and Architecture Engineering, Hebei United University, Tangshan, P.R. China
\end{abstract}
${ }^{2}$ Department of Foreign Languages, Tangshan College, Tangshan, P.R. China

*Corresponding author: E-mail: wanghao1689@gmail.com

(Received: 15 January 2013;

Accepted: 5 November 2013)

AJC-14339

\begin{abstract}
According to the problem of lightly polluted water in Wenyu river which secondary effluent was difficult to reach the water quality standard IV, some operation parameters of a new kind of constructed wetland technology were studied. The constructed wetland made water clean by the absorption of cobble layer, large and small particle volcanic rock layers, find sand layer, etc., the absorption of plants and the degradation of microorganisms. The results showed the optimal hydraulic retention time was 7 days. Meanwhile, after the treatment of constructed wetland, the effluent concentration of ammonia nitrogen and total nitrogen were from $0.2-1.1 \mathrm{mg} / \mathrm{L}$ and from 3.0-6.8 mg/L, respectively and the ammonia nitrogen and total nitrogen removal rates were from 54.2 to $91.7 \%$ and from 29.2 to $68.8 \%$, respectively.
\end{abstract}

Key Words: Subsurface wetland, Volcanic rocks, Lightly polluted water, Nitrogen.

\section{INTRODUCTION}

With the increasing contradictions between the shortage of freshwater resources and people's living standards improve, more and more arduous task of environmental protection water happened. Because of its low investment, good water quality, shock resistance, simple operation, construction and operation of low-cost, easy maintenance, high ammonia removal efficiency $^{1-3}$, constructed wetland was applied to sewage treatment and environmental and ecological construction combine in recent years. More and more countries accepted and applied to it widely ${ }^{4-6}$. Meanwhile, constructed wetlands have been widely used in the treatment of urban sewage, agricultural wastewater, poultry and livestock farming, wastewater, mine drainage, dye wastewater, urban storm water, highway rain, airport rain industrial wastewater ${ }^{5,7-11}$. In this paper, the Wenyu micro-polluted water out of the water, such as ammonia and total nitrogen pollution indicators could not reach the requirements of the environmental quality standards for surface water IV water, subsurface flow constructed wetland technology for micro-polluted water for processing, in order to further removal of ammonia nitrogen and total nitrogen pollutants, effluent water quality to meet higher standards.

\section{EXPERIMENTAL}

Four layers of the filler within the constructed wetland laying, from bottom to top of the (a) first layer of gravel layer, a particle diameter of 5-6 mm with a thickness of $10 \mathrm{~cm}$; (b) second layer for a large particle diameter of volcanic layers, particle diameter of 2-3 mm with a thickness of $10 \mathrm{~cm}$; (c) third layer of the smaller-diameter volcanic layers, the particle size of 0.5-2.0 mm with a thickness of $10 \mathrm{~cm}$; (d) uppermost layer of fine sand of height $20 \mathrm{~cm}$.

Water perforated pipe collected the efflux. Water by a peristaltic pump into the artificial wetlands, water from the bottom, through the gravel layer, aniseed diameter volcanic rocks, volcanic rocks and fine sand soil of small particle size, absorption through the layers of filler adsorption and canna plants, micro-organisms degradation process, the treated water collected by the perforated pipe efflux.

Matrix characteristics: Volcanic rock was selected as filter matrix, which is the instant condensation product of volcanic eruptions and has a high porosity, large surface area, hard texture. Meanwhile, it was a kind of constructed wetland material and appeared without tip granular shape of flow resistance small and easy to plug, water distribution uniform cloth air, surface roughness, soil microbial attachment fast growth; volcanic rocks is a natural cellular porous filter material, excellent water absorption, but also can absorb organic matter, nitrogen, phosphorus and as better bacteria the growth environment of the micelle; practice has proved that can endure the hydraulic shearing action of the different intensity, life is much longer than the other filter, through the characterization of its performance indicators (Table-1). 
TABLE-1

PERFORMANCE INDEX OF VOLCANIC ROCKS

\begin{tabular}{lc}
\hline \multicolumn{1}{c}{ Parameter } & Measuring results \\
\hline Volume weight $(\%)$ & 740 \\
Specific density & $1: 1.29$ \\
Percentage of moisture $(\%)$ & $0.9-1.0$ \\
Porosity $(\%)$ & $73-82$ \\
Specific surface area $\left(\mathrm{m}^{2} / \mathrm{g}\right)$ & $13.6-25.5$ \\
Compression strength $(\mathrm{Mpa})$ & 5.78 \\
Shear resistance $(\mathrm{Mpa})$ & 3.98 \\
Friction attrition rate $(\%)$ & $<1$ \\
Biofilm culturing time $(\mathrm{h})$ & 27 \\
Hydrochloric acid soluble rate $(\%)$ & $<1.0$ \\
\hline
\end{tabular}

Since the test run which season of autumn and winter, based on experience canna removal of pollutants at low temperatures still like. Plant grown in artificial wetlands selected canna, canna roots absorb significant functionality by transforming pollutants; role in promoting it around the roots of oxygen-rich environment for aerobic microbial activity, such biological effects of its purifying effect has been greatly improved.

Influent quality: The raw wastewater, secondary effluent of wastewater treatment plants, was collected from Wenyu river in Beijing. The composition of the influent used in all experiments is shown in Table-2.

\begin{tabular}{|c|c|}
\hline \multicolumn{2}{|c|}{$\begin{array}{c}\text { TABLE-2 } \\
\text { CHARACTERISTICS OF THE WASTEWATER } \\
\text { SAMPLE USED IN THE EXPERIMENTS } \\
\end{array}$} \\
\hline Parameter & Concentration \\
\hline $\mathrm{pH}$ & $6.5-8.0$ \\
\hline Ammonia nitrogen $\left(\mathrm{NH}_{3}-\mathrm{N}\right)\left(\mathrm{mg} \mathrm{L}^{-1}\right)$ & $2.4-5.7$ \\
\hline Total nitrogen $(\mathrm{TN})\left(\mathrm{mg} \mathrm{L}^{-1}\right)$ & $9.6-15.1$ \\
\hline
\end{tabular}

Experimental methods: Hydraulic retention time was the obvious effect of pollutants removal in constructed wetland. Peristaltic pump from the secondary reaction pool pumps into the constructed wetlands, by controlling the speed of the peristaltic pump to determine the constructed wetland water flows and thus determine the constructed wetland hydraulic dwell time, respectively, water force dwell time for $4 d, 5 d, 6 d, 7 d$, $8 \mathrm{~d}, 9 \mathrm{~d}, 10 \mathrm{~d}$, ammonia nitrogen and total nitrogen removal of the water of the artificial wetland monitoring.

\section{RESULTS AND DISCUSSION}

Removal of nitrogen: As is shown in Fig. 1, controlling the hydraulic retention time of 4-10 d after constructed wetland treatment effluent ammonia concentration range of 0.2 $1.1 \mathrm{mg} / \mathrm{L}$, the removal rate of 54.2 to $91.7 \%$, total nitrogen concentration range of 3.0-6.8 $\mathrm{mg} / \mathrm{L}$, the removal rate of 29.2 to $68.8 \%$, with the hydraulic retention time, ammonia nitrogen and total nitrogen concentration decreased significantly. The removal rate increased more than 7 days, but the residence time, the removal rate were not changed significantly. The average concentration of ammonia water $0.3 \mathrm{mg} / \mathrm{L}$, the removal rate of $87.5 \%$, total nitrogen removal is also very good, the average effluent concentration of $3.2 \mathrm{mg} / \mathrm{L}$, the removal rate of $66.7 \%$. Accordingly determine the best constructed wetland hydraulic retention time of 7 days. The mechanism of the under-

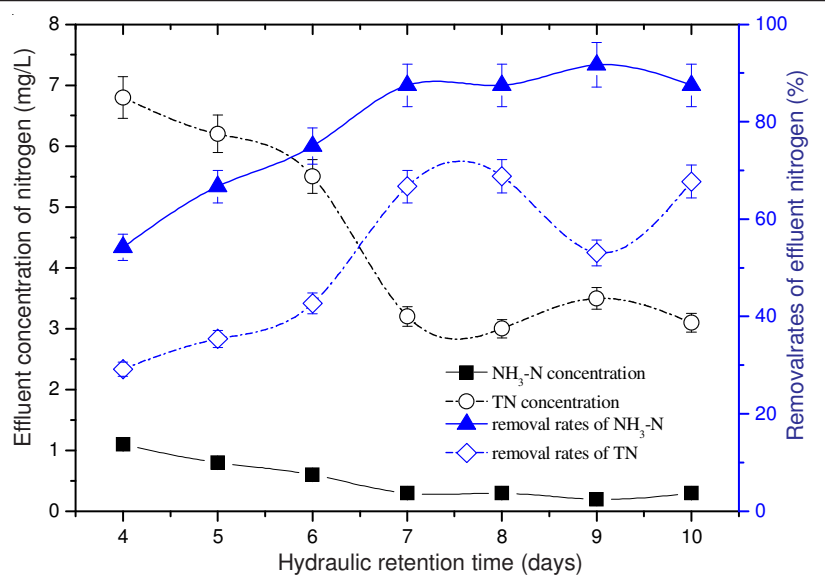

Fig. 1. Removal effect of ammonia nitrogen and total nitrogen by hydraulic retention time

current of wetlands purify sewage is generally believed that the use of plant-microbial ecosystem-filler reaction the triple synergy purification of sewage, physics, chemistry and biochemistry. Physical effects of filtration, sedimentation, sewage into wetlands, matrix and dense plant stems, leaves and roots can filter retention of suspended solids in the sewage and deposited in the matrix, chemical reactions mainly refers to the chemical precipitation, adsorption, ion exchange, antagonistic and redox reactions, etc. These chemical reactions occur primarily depends on the selected type of substrate, biochemical reactions, mainly refers to microorganisms in the aerobic, facultative and anaerobic conditions, by ring opening, broken bonds decomposition simple molecules, small molecules such as the role of pollutants degradation and removal, which constitute artificial wetlands of the four basic elements all have separate purify sewage capacity, especially wetland substrate microbial group classes in constructed wetland sewage purification process play a very important role. Nitrogen removal within the wetland has good nitrification and denitrification bacteria habitats provide good conditions for the removal of nitrogen.

\section{Conclusion}

Subsurface flow constructed wetlands, the laying of gravel, volcanic rock, fine sand to build a four-layer filter bed and the plant canna, through long-term test, the constructed wetlands for the removal of various pollutants were good. Testing to determine the best artificial wetland hydraulic residence time of 7 days, remove all obvious indicators of a variety of constructed wetlands for water pollution, effluent quality reaches IV water environmental quality standards and reliable operation. Artificial wetland treatment, the average concentration of ammonia water $0.3 \mathrm{mg} / \mathrm{L}$, the removal rate of $87.5 \%$, total nitrogen removal effect is also very good, the average effluent concentration of $3.2 \mathrm{mg} / \mathrm{L}$, the removal rate of $66.7 \%$.

\section{ACKNOWLEDGEMENTS}

The financial support of this research by Hebei Construction Science and Technology Research Program (2013-143) in P.R. China and Scientific Research Foundation for Doctor of HEUU (35394701) are gratefully acknowledged. 


\section{REFERENCES}

1. N. Mehrdadi, A. Rahmani, A.A. Azimi and A. Torabian, Asian J. Chem., 21, 5245 (2009).

2. H. Wang, X.W. He, T.Q. Liu and C.H. Zhang, Fresenius Environ. Bull., 20, 2890 (2011).

3. H.Wang and L. Zhang, Asian J. Chem., 24, 5299 (2012).

4. C.C. Tanner, J.P.S Sukias and P.U. Martin, Water Res., 32, 3046 (2007).

5. G.D. Ji, T.H. Sun, Q.X. Zhou, X. Sui, S.J. Chang and P.J. Li, Ecol. Eng., 18, 459 (2002)
6. Y.F. Lin, S.R. Jing, D.Y. Lee and T.W. Wang, Aquaculture, 209, 169 (2002).

7. F. Rivera, A. Warren and C.R. Curds, Water Sci. Technol., 35, 271 (1997).

8. C.J. Richardson and S.S. Qian, Environ. Sci. Technol., 33, 1545 (1999).

9. N. Korboulewsky, R.Y. Wang and V. Baldy, Bioresour. Technol., 105, 9 (2012).

10. C.C. Tanner, J.P.S. Sukias and P.U. Martin, Water Res., 32, 3046 (2007).

11. R.M. Gersberg, B.V. Elkins and C.R. Goldman, Water Res., 17, 1009 (1983). 